\title{
Pemberitaan Lesbi, Gay, Biseksual, Transgender (LGBT) Di Televisi Terhadap Tingkat Kecemasan Orang Tua (Survei Warga Kelurahan Pondok Cina, Kecamatan Beji, Depok, Jawa Barat)
}

\author{
Afif Rahman Kurnia ${ }^{6}$, Rini Riyantini ${ }^{7}$ \\ Universitas Pembangunan Nasional Veteran Jakarta \\ afifrahmankurnia@gmail.com,rinihoriyantini@gmail.com
}

\begin{abstract}
ABSTRAK
LGBT merupakan masalah sosial yang sedang marak terjadi di Indonesia, dan bahkan sudah menyebar di seluruh dunia, sehingga menjadi topik pemberitaaan pada media televisi. Penulis menggunakan teori efek media massa sebagai dasar acuan teori yang sesuai dengan masalah yang ingin diteliti. Tujuan dari penelitian ini untuk mengukur besarnya pengaruh pemberitaan LGBT di televisi terhadap tingkat kecemasan orang tua. Survei dilakukan pada warga kelurahan Pondok Cina, kecamatan Beji, Depok, Jawa Barat dengan teknik purpose sampling. Pengaruh pemberitaan LGBT diukur berdasarkan dimensi penting, besaran, kebaruan, kedekatan, ketermukaan, dan sentuhan, terhadap tingkat kecemasan, yang diukur berdasarkan indikator gelisah, rasa tidak senang, tegang, dan tidak aman dengan menggunakan analisis regresi. Hasil menunjukkan, besarnya pengaruh pemberitaan LGBT di televisi terhadap tingkat kecemasan orang tua, sebesar $50 \%$. Adapun saran, stasiun televisi khususnya program pemberitaan, haruslah menginformasikan sesuai fakta, dan sumber yang jelas, serta memberikan suatu informasi bahwasanya peristiwa tersebut memiliki rasa aman untuk masyarakat yang melihat pemberitaan tersebut.
\end{abstract}

Kata Kunci : Pemberitaan, LGBT, Kecemasan, orang tua

\section{ABSTRACT}

$L G B T$ is a social problem that is rife in Indonesia, and has even spread throughout the world, making it a topic of reporting on television media. The author uses the theory of mass media effects as a basis for theoretical references that are appropriate to the problem to be studied. The purpose of this study was to measure the magnitude of the influence of LGBT reporting on television on parental anxiety levels. The survey was conducted on residents of Pondok Cina, Beji sub-district, Depok, West Java using a purpose sampling technique. The effect of LGBT reporting is measured based on important dimensions, magnitude, novelty, closeness, surface, and touch, on the level of anxiety, which is measured by indicators of anxiety, displeasure, tension, and insecurity using regression analysis. The results show, the magnitude of the influence of LGBT reporting on television on the level of anxiety of parents, by $50 \%$. As for advice, namely in this case television stations, especially news programs, must inform according to facts, and clear sources, and provide information that the event has a sense of security for people who see the news.

Keywords: News, LGBT, Anxiety, parents

\footnotetext{
${ }^{6}$ Mahasiswa Program Studi Ilmu Komunikasi FISIP UPN Veteran Jakarta

${ }^{7}$ Dosen Program Studi Ilmu Komunikasi FISIP UPN Veteran Jakarta
} 


\section{PESRSESI}

\section{PENDAHULUAN}

Kebutuhan informasi yang terus meningkat membuat manusia terus mencari informasi baru yang belum diketahui. Salah satu media yang berperan aktif dalam menyebarkan informasi kepada masyarakat adalah televisi (TV). TV masih sangat populer dikalangan masyarakat sebagai media yang efektif dalam menyebarkan informasi yang dibutuhkan masyarakat, sehingga tidak aneh jika televisi merupakan salah satu media yang mempunyai dampak yang cukup besar dalam pemahaman akan sesuatu seperti fenomena atau peristiwa yang terjadi.

Penelitian ini mengenai pemberitaan lesbian, gay, biseksual dan transgander (LGBT) yang saat ini banyak terjadi di kalangan masyarakat. LGBT merupakan masalah sosial yang terjadi di Indonesia dan diluar negeri bahkan sekarang sudah menyebar di penjuru dunia. Dalam penelitian sebelumnya yang dilakukan oleh Nurkholis (2013) dengan judul faktor yang dapat melatarbelakangi lesbian. Lesbian adalah istilah bagi perempuan yang mengarahkan orientasi seksualnya kepada sesama perempuan. Istilah ini juga merujuk kepada perempuan yang mencintai perempuan baik secara fisik, seksual, emosional, atau secara spiritual.

Dalam penelitian Kristina (2012) informasi dan homoseksual/Gay, homo seksualitas adalah kesenangan yang terus menerus terjadi dengan pengalaman erotis yang melibatkan kawan sesama jenis, yang dapat atau mungkin saja tidak dapat dilakukan dengan orang lain atau dengan kata lain, homo seksualitas membuat perencanaan yang disengaja untuk memuaskan diri dan terlibat dalam fantasi atau perilaku seksual dengan sesama jenis.

LGBT di Indonesia setidaknya sudah ada sejak era 1960-an. Ada yang menyebut dekade 1920-an. Namun, pendapat paling banyak menyebut fenomena LGBT ini sudah mulai ada sekitar dekade 60-an. Lalu, ia berkembang pada dekade 80-an, 90-an, dan meledak pada era milenium 2.000 hingga sekarang. Dilansir dari Republika.co.id (23 Januari 2016, 14:42 WIB) disebutkan bahwa: Kota Jawa Barat memiliki angka perkumpulan kaum LGBT terbanyak sebanyak 300.198 orang yang terindikasi merupakan gay. Jawa Tengah memiliki penderita gay dengan jumlah 218.227. DKI Jakarta? Sebanyak 27.706 warga ibu kota. Fenomena LGBT awalnya terjadi di negara luar, disana memang biasa melihat pemandangan seperti itu layaknya seorang pasangan yang romatis tapi tidak halnya di indonesia yang merasa aneh seseorang sesama jenis bermesraan ditepat umum atau tinggal bersama dalam satu rumah, bahkan di laur negeri kaum gay, lesbian dan sejenisnya mempunyai bendera sendiri yaitu bendera pelangi.

Pada ajaran agama Islam LGBT merupakan penyimpangan orientasi seksual yang bertentangan dengan fitrah manusia, agama dan adat masyarakat Indonesia. Dalam Islam LGBT dikenal dengan dua istilah, yaitu Liwath (gay) dan Sihaaq (lesbian). Sejak zaman Nabi Luth 'Alaihis salam kaumnya yang pertama kali melakukan perbuatan ini. 


\section{PERSERES}

Komunitas LGBT meminta kepada pemerintah agar dilegalkan atas kesetaraan hak dengan hakikat masyarakat pada umumnya. Isu LGBT kini kembali merebak, karena adanya lembaga konseling Support Group and Resource Center on Sexuality Studies (SGRC) di Universitas Indonesia (UI) yang membuat kalangan itu kembali eksis di kampus. Aktifnya SGRC pun mengundang pertanyaan mengingat pendiri SGRC juga berasal dari kalangan LGBT. Republika.co.id (28 Maret 2016, 14:42 WIB). Tidak hanya mendapat respon dari pihak kampus, SGRC-UI pun menuai komentar dari pihak eksternal kampus. Ketua PP Pemuda Muhammadiyah Dahnil Anzar Simanjuntak mengatakan, hal tersebut merupakan kemunduran jika sikap kampus di Indonesia harus mengikuti tradisi kampus Barat. Kampus di Indonesia harus memiliki sikap sendiri (Republika Online, 22 Januari 2016). Menteri Riset Teknologi dan Pendidikan Tinggi M. Nasir pun ikut berkomentar soal kasus yang menerpa SGRC-UI, beliau mengatakan bahwa LGBT semestinya tidak boleh masuk kampus sebab hal tersebut bisa merusak moral bangsa dan kampus sebagai penjaga moral semestinya harus bisa menjaga betul nilai-nilai asusila dan nilai luhur bangsa Indonesia (Antara News, 23 Januari 2016). Banyaknya respon yang berdatangan, membuat pihak SGRC-UI turut memberikan klarifikasi melalui halaman resmi mereka (https://sgrcui.wordpress.com) mengungkapkan bahwa kehadiran mereka bukan untuk mendoktrin, melainkan SGRC-UI hanya membantu para LGBT dalam menemukan solusi masalah yang mereka hadapi.

SGRC-UI pun menegaskan bahwa organisasi mereka bukanlah komunitas kencan atau tempat mencari jodoh bagi kelompok LGBT, melainkan sebagai wadah kajian mengenai isu gender, seksualitas, feminisme, hak tubuh, patriarki, gerakan pria dan wanita, bahkan buruh. Pendiri dan anggota SGRC-UI terdiri dari mahasiswa, alumni, serta dosen Universitas Indonesia. Hal tersebut pula yang melatarbelakangi pencantuman UI dalam nama organisasi tersebut. Ada pula beberapa contoh pemberitaan LGBT dikalangan artis yang bermunculan seperti kasus pembicaraan artis pria melalui handphone dengan sesama jenisnya. dan ada pula artis pria yang menjadi tersangka akibat tindak asusila sesama jenis,

hal ini sangat berpengaruh terhadap presepsi masyarakat tentang suatu peristiwa yang ditayangan melalui media televisi. Semua itu akan berpengaruh besar terhadap pola pikir masyarakat atas peristiwa yang diberitakan terkait dengan terpaan yang dihadirkan oleh sebuah media massa, dengan ditayangkannya berita mengenai LGBT yang mebuat sikap orang tua untuk lebih waspada terhadap pergaulan anak remajanya, karena orang tua harus mengambil sikap dalam mengawasi pergaulan anaknya di luar rumah maupun diluar lingkungan keluarganya. Penelitian sebelumnya yaitu Dewi (2013) mengukur pengaruh tayangan berita kriminal di televisi terhadap kecemasan ibu rumah tangga. Tayangan berita kriminal mempengaruhi kecemasan ibu rumah tangga sebesar 28,3\% dan selebihnya 71,70\% 


\section{PERSESPSI}

dipengaruhi oleh faktor-faktor lain yang tidak diteliti misalnya pengalam individu akan tindak kriminal Semakin sering para ibu menonton tayangan berita kriminal maka semakin tinggi tingkat kecemasan akan tindak kejahatan pada anak-anak mereka. Terkait dengan permasalahan yang diangkat oleh peneliti mengambil judul Pemberitaan Lesbian, Gay, Biseksual, Transgander (LGBT) Di Televisi terhadap Tingkat Kecemasan Orang Tua (Survei Warga Kelurahan Pondok Cina, Kecamatan Beji, Depok, Jawa Barat). Penulis mengambil survei peneliti pada warga Kelurahan Pondok Cina, Kecamatan Beji, Depok, Jawa Barat

Tujuan Penelitian untuk mengukur besarnya pengaruh pemberitaan Lesbian, Gay, Biseksual, Transgender (LGBT) di televisi terhadap tingkat kecemasan orang tua pada warga Kelurahan Pondok Cina, Kecamatan Beji, Depok, Jawa Barat.

\section{KAJIAN LITERATUR}

Media massa memiliki beberapa fungsi yaitu memberikan informasi, mendidik, memengaruhi, dan juga dapat menghibur.media massa berperan untuk memberikan suatu informasi kepada masyarakat seperti kejadian ataupun peristiwa yang dapat disampaikan kepada khalayak. Artinya dengan adanya media massa khalayak mengetahui segala informasi yang sedang terjadi. Salah satu media massa yang dapat memengaruhi khalayak dengan mudah karena bersifat audiovisual yaitu televisi. Informasi yang disampaikan televisi berupa peristiwa yang terjadi di tengah-tengah masyarakat saat ini yaitu LGBT, informasi atau pemberitaan LGBT yang diberikan oleh media massa baik itu media cetak, elektronik maupun media online secara terus menerus di sampaikan kepada khalayak secara tidak langsung pemberitaan tersebut dapat memengaruhi sikap kecemasan dan pola pikir khalayak luas. karena dalam memberikan pemberitaan LGBT media televisi mampu menyebarkan pemberitaan tersebut meluas dan serempak dengan waktu yang bersamaan artinya pemberitaan LGBT dapat diterima oleh siapa saja dan dimana saja tanpa mengenal usia, jenis kelamin, dan suku bangsa.

\section{Televisi}

Televisi hadir dengan sifatnya yang audiovisual dan cinematography. Televisi dapat memberikan informasi yang jelas kepada khalayak berupa pemberitaan. Media televisi memiliki dampak indentifikasi optik yang tajam bagi pemirsanya. Menurut Ardianto (2014) fungsi televisi sama dengan media massa lainnya seperti surat kabar, dan radio siaran yakni berfungsi untuk memberi informasi, mendidik, dan menghibur.Sedangkan menurut Baksin (2006), mendefinisikan bahwa televisi merupakan hasil dari produk teknologi tinggi (hi-tech) yang mampu menyampaikan berbagai informasi dalam bentuk 


\section{PERSERES}

audiovisual gerak. Televisi adalah medium komunikasi yang paling akrab dengan masyarakat karena kemampuannya mengatasi faktor jarak, ruang dan waktu (Surbakti, 2008).

Morissan (2010) menjelaskan, di antara media-media yang lain, media televisi juga memiliki kelebihan dan kekurangan, antara lain :

a. Kelebihan televisi

1. Kesan Realistik, yaitu arena sifatnya yang visual dan merupakan kombinasi warna-warna suara dan gerakan maka informasi yang disampaikan dari televisi terkesan hidup dan nyata.

2. Masyarakat Lebih Tanggap, yaitu masyarakat akan lebih cepat tanggap karena penyajian yang lebih detil dibandingkan dengan media lain.

3. Repetisi/pengulangan, yaitu adanya pengulangan untuk tayangan-tayangan tertentu, sehingga akan menguntungkan bagi masyarakat yang tidak dapat menyaksikannya.

4. Adanya pemilihan area siaran (zoning) dan jaringan kerja (networking) yang mengefektifkan perjangkauan masyarakat. Seorang jurnalis dapat menggunakan satu atau kombinasi banyak stasiun televisi sekaligus untuk memuat informasinya, atau bahkan dapat juga membuat jaringan kerja dengan stasiun televisi lainnya sehingga informasinya dapat ditayangkan di seluruh stasiun televisi.

5. Terkait erat dengan media lain, yaitu informasi yang ditayangkan oleh televisi dapat dikatakan kurang detil, apabila konsumen memerlukan informasi yang lebih lanjut dapat diperoleh informasinya pada media lainnya, khususnya media cetak seperti koran.

b. Kelemahan televisi

1. Masa putar durasi pendek 30-60 detik, memerlukan frekuensi pemasangan yang lebih seringa tau lebih besar.

2. Tidak dapat menyampaikan pesan yang panjang karena keterbatasan waktu.

Dari penjelasan di atas peneliti menyimpulkan bahwa televisi merupakan salah satu perangkat komunikasi massa dalam bentuk media elektronik. Penggunaan media televisi oleh khalayak tidak diragukan lagi keunggulan televisi yang menawarkan audio dan visual, akan lebih mudah menyampaikan isi pesan agar lebih dipahami dan di mengerti oleh khalayak.

Dalam televisi semua acara tersusun secara teratur dan sistematis karena adanya program. Program adalah segala hal yang ditampilkan stasiun penyiaran untuk memenuhi kebutuhan audiennya. Program atau acara yang disajikan adalah faktor yang membuat audien tertarik untuk mengikuti siaran yang dipancarkan stasiun penyiaran. Program yang baik akan mendapatkan penonton yang lebih besar, sedangkan acara yang buruk tidak akan mendapatkan penonton. Morissan (2008).

Terkait dengan penelitian ini, bahwa dengan media televisi masyarakat dapat memeroleh informasi yang lebih lengkap, terupdate, teraktual dan selain itu juga masyarakat tidak akan ketinggalan informasi. Dengan televisi masyarakat dapat melihat dan memahami suatu peristiwa, karena apa yang ditampilkan di televisi itu berupa audiovisual. Dalam televisi terdapat dua jenis besar program yaitu informasi (berita) dan hiburan (entertainment). Dalam penelitian ini televisi memberikan informasi kepada khalayak berupa pemberitaan mengenai LGBT, pemberitaan tersebut diberikan secara terusmenerus karena merupakan suatu peristiwa yang terjadi di tengah-tengah masyarakat. Pemberitaan LGBT yang disiarkan oleh televisi juga merupakan media yang dapat memengaruhi khalayak salah 


\section{PERSESPS}

satunya program berita LGBT tersebut. Dampak dari pemberitaan LGBT yang ada pada media televisi, dapat memberikan pengaruh yang kuat kepada pemirsanya di antaranya yaitu timbul kecemasan orang tua.

\section{Efek Media Massa}

Dalam efek media massa, bentuk media saja sudah memengaruhi khalayak. ada lima macam jenis efek dari kehadiran media massa seperti: efek ekonomis, efek sosial, efek pada penjadwalan kegaiatan, dan efek pada perasaan orang terhadap media McLuhan (Ardianto, 2014). Media massa juga menimbulkan efek kognitif, efek afektif dan efek behavioral, Ardianto (2014) yaitu:

a. Efek kognitif adalah akibat yang timbul pada diri komunikan yang sifatnya informatif bagi dirinya. Dalam efek kognitif ini tentang bagaimana media massa dapat membantu khalayak dalam mempelajari informasi yang bermanfaat untuk mengembangkan keterampilan kognitifnya dengan melalui media massa, seseorang dapat memperoleh informasi.

b. Efek afektif ini kadarnya lebih tinggi dari pada efek kognitif. Tujuan dari komunikasi massa sendiri bukan hanya sekedar memberitahu khalayak tentang sesuatu tetapi lebih dari itu, khalayak di harapkan dapat turut merasakan perasaan iba, terharu, sedih, gembira, marah dan sebagainya.

c. Efek behavioral merupakan suatu akibat yang ditimbulkan pada diri khalayak dalam bentuk perilaku, sifat, tindakan atau kegiatan. Efek ini akan mengungkapkan tentang efek komunikasi massa pada perilaku, sifat, tindakan dan gerakan khalayak yang akan tampak dalam kehidupan mereka sehari hari.

Teori mengenai efek media massa dijelaskan dengan Teori Dependensi. Teori ini dikembangkan oleh Sandra Ball-Rokeach dan Melvin L DeFleur (1976) yang mengemukan mengenai kondisi struktural suatu masyarakat yang akan menimbulkan kecenderungan terjadinya suatu efek media massa. Teori ini pada dasarnya merupakan pendekatan struktur sosial yang bermula dari gagasan mengenai sifat suatu masyarakat modern (atau masyarakat massa). Media massa dapat dianggap sebagai sistem informasi yang memiliki peran penting dalam proses pemeliharaan, perubahan, dan konflik pada tatanan masyarakat, kelompok atau individu dalam aktivitas sosial.

Pemikiran terpenting dari teori ini adalah bahwa dalam masyarakat modern, audience menjadi tergantung pada media massa sebagai sumber informasi bagi pengetahuan tentang, dan orientasi kepada, apa yang terjadi dalam masyarakatnya.

\section{Pemberitaan}

Menurut Assegaf (Barus, 2010) berita adalah "Suatu laporan laporan tentang fakta atau ide yang terkini yang dipilih oleh wartawan untuk disiarkan yang dapat menarik perhatian pembaca, entah karena luar biasa atau entah karena pentingnya atau karena akibat yang ditimbulkannya atau entah karena yang mencangkup segi-segi human interest seperti humor, emosi dan ketegangan".

Pemberitaan LGBT di televisi termasuk kedalam berita berat atau hard news karena permasalahan LGBT yang terjadi merupakan suatu informasi penting dan menarik yang harus segera disiarkan agar 


\section{PERSESPS}

khalayak mengetahui secepatnya. Hampir semua media massa membahas tentang LGBT, karena populasinya yag sudah menyebar dan meningkat pertahunnya. LGBT merupakan suatu permasalahan yang berada di tengah-tengah masyarakat.Pemberitaan LGBT di televisi dapat menjadikan pembelajaran bagi khalayak yang menyaksikannya dan memahami faktor-faktor penyebab LGBT.Selain itu informasi yang disampaikan dalam bentuk berita televisi mengenai LGBT secara tidak langsung dapat merubah sikap atau timbulnya kecemasan terhadap khalayak khusunya orang tua.

\section{Unsur-Unsur Berita}

Barus (2010, hlm.32) mengatakan bahwa untuk memilah apakah suatu kejadian memiliki nilai berita atau tidak, haruslah dapat melihat unsur-unsur sebagai berikut :

1. Penting (significane) : mempunyai pengaruh yang besar terhadap kehidupan orang banyak atau kejadiannya mempunyai akibat atau dampak yang luas terhadap kehidupan khalayak.

2. Besaran (magnitute) : sesuatu yang besar dari segi jumlah, nilai, atau angka yang besar hitungannya sehingga pasti menjadi suatu yang berarti dan menarik untuk diketahui oleh banyak orang.

3. Kebaruan (timelines) : memuat peritiwa yang baru saja terjadi, karena kejadiannya belum lama, hal ini menjadi aktual atau masih hangat dibicarakan umum. Aktual (terkini) berkaitan dengan tenggang waktu bahwa kejadian tersebut bukan berita basi, atau terlambat memenuhi waktu pemuatan yang sudah ditetapkan pemimpin redaksi.

4. Kedekatan (proximity) : memiliki kedekatan jarak (geografis) ataupun emosional dengan khalayak. Termasuk kedekatan karena propfesi, minat, bakat hobi, dan perhatian khalayak. Kaitan menimbulkan rasa emosional terutama orang tua korban dan masyrakat atau orang banyak.

5. Ketermukaan (prominence): hal-hal yang mencuat dari diri seseorang atau suatu benda, tempat, atau kejadian. Suatu peristiwa yang menyangkut orang terkenal atau suatu yang dikenal oleh masyarakat menjadi berita penting untuk diketahui oleh khalayak.

6. Sentuhan manusiawi (human interest) : sesuatu yang menyentu rasa kemanusiaan, mengguga hati, dan minat.

\section{Kecemasan}

Kecemasan dapat juga terjadi pada orang normal. Biasanya normal ini disebut khawatiran atau was-was, yaitu rasa takut yang tidak jelas, tetapi terasa sangat kuat, Sarwono (2010). Sedangkan menurut Kelly (Matthew, 2013) mendefinisikan bahwa kecemasan sebagai pengakuan bahwa kejadian-kejadian yang dihadapi seseorang terletak di luar jangkauan pemenuhan system konstruknya. Karena fungsi utama sistem konstruk adalah mengantisipasi kejadian-kejadian secara akurat, kecemasan juga berarti kebingungan dan teka teki dalam kehidupan sehari-hari. Rasa cemas akan muncul dengan sendirinya karena ada sesuatu yang tidak diinginkan. Siapa saja bisa merasakan kecemasan, tak terkecuali orang tua.

Penelitian sebelumnya yang dilakukan oleh Siska (2003) mengatakan bahwa kecemasan ialah suatu pengalaman subjektif mengenai ketegangan mental yang menggelisahkan sebagai reaksi umum dan ketidak mampuan menghadapi masalah atau adanya rasa aman. Perasaan yang tidak menyenangkan ini umumnya menimbulkan gejala-gejala fisiologis (seperti gemetar, berkeringat, detak jantung meningkat, 


\section{PERSESPSI}

dan lain-lain) dan gejala-gejala psikologis (seperti panik, tegang, bingung, tak dapat berkonsentrasi,dan sebagainya).

Perbedaan intensitas kecemasan tergantung pada keseriusan ancaman dan efekivitas dari operasioperasi keamanan yang dimiliki seseorang. Mulai munculnya perasaan-perasaan tertekan, tidak berdaya akan muncul apabila orang tidak siap menghadapi ancaman. Menurut Buklew dalam Siska (2003, hlm 68) tanda-tanda kecemasan bisa dilihat dari dua sisi, yaitu: “a) Tingkat psikologis, seperti tegang, bingung, khawatir, sulit berkonsentrasi, dll, b) Tingkat fisiologis, yaitu kecemasan yang sudah mempengaruhi fisik, terutama fungsi sistem syaraf seperti sukar tidur, jantung berdebar, keringat berlebihan, sering gemetar dan perut mual".

Dalam kaitannya dengan jenis kelamin, Myers (1983) dalam siska (2003, hlm.68) mengatakan bahwa perempuan lebih cemas akan ketidak mampuannya dibanding dengan laki-laki. Laki-laki lebih aktif, eksploratif, sedangkan perempuan lebih sensitif. Menurut Morris ) dalam siska (2003, hlm.68), sifat sensitif pada perempuan membuat dirinya lebih mudah dipengaruhi rasa khawatir akan efek-efek yang timbul. kecemasan timbul akibat suatu hal yang tidak diinginkan menimpa dirinya atau orang terdekatnya.

Kecemasan menyebabkan munculnya rasa gelisah, tegang, tidak tenang, dan merasa tidak aman. Terkait dengan penelitian yang diangkat oleh penulis rasa kecemasan juga akan timbul dengan melihat media massa dengan pemberitaan yang terjadi ditengah-tengah masyarakat yaitu LGBT, akibat pemberitaan tersebut orang tua dirinya tidak mau orang terdekatnya (anak) terkena atau terjerumus di dalam suatu peristiwa tersebut. Maka timbulah sikap kecemasaan akibat media massa tersebut.

\section{Lesbi, Gay, biseksual, atau transgender (LGBT)}

Istilah LGBT berasal dari kata Lesbi, Gay, biseksual, atau transgender. Lesbian adalah istilah bagi perempuan yang mengarahkan orientasi seksualnya kepada sesama perempuan. Istilah ini juga merujuk kepada perempuan yang mencintai perempuan baik secara fisik, seksual, emosional, atau secara spiritualNurkholis (2013).

Homoseksual/Gay adalah kesenangan yang terus menerus terjadi dengan pengalaman erotis yang melibatkan kawan sesama jenis, yang dapat atau mungkin saja tidak dapat dilakukan dengan orang lain atau dengan kata lain, homoseksualitas membuat perencanaan yang disengaja untuk memuaskan diri dan terlibat dalam fantasi atau perilaku seksual dengan sesama jenisKristina (2012).

Biseksual adalah orientasi seksual yang mempunyai ciri-ciri berupa ketertarikan estetis, cinta romantis, dan hasrat seksual kepada pria dan wanita, adalah istilah untuk orang yang tertarik secara seksual baik itu terhadap laki-laki maupun perempuan. Biseksual juga didefinisikan sebagai orang yang 


\section{PERSESPS}

memiliki ketertarikan secara psikologis, emosional dan seksual kepada laki-laki dan perempuan Sianturi (2011).

Transgender adalah istilah yang digunakan untuk mendeskripsikan orang yang melakukan, merasa, berpikir atau terlihat berbeda dari jenis kelamin yang ditetapkan saat mereka lahir selain kasus transgender atau transeksual juga terdapat kasus kebingungan jenis kelamin dari orang yang memiliki kelainan atau cacat bawaan karena memiliki dua alat kelamin yaitu kelamin laki-laki dan perempuan. Orang berkelamin ganda yang tidak jelas apakah status kelaminnya membuat mereka merasa berbeda dengan yang lainnya dan mereka menganggap dirinya tidak normal dan berbeda dengan yang lainnya. Mereka merasa bahwa dirinya bukan merupakan gender yang sekarang membentuk dirinya, sehingga mereka berperilaku dan berpenampilan seperti gender yang mereka inginkan Rassan (2013).

Kerangka Pikir :

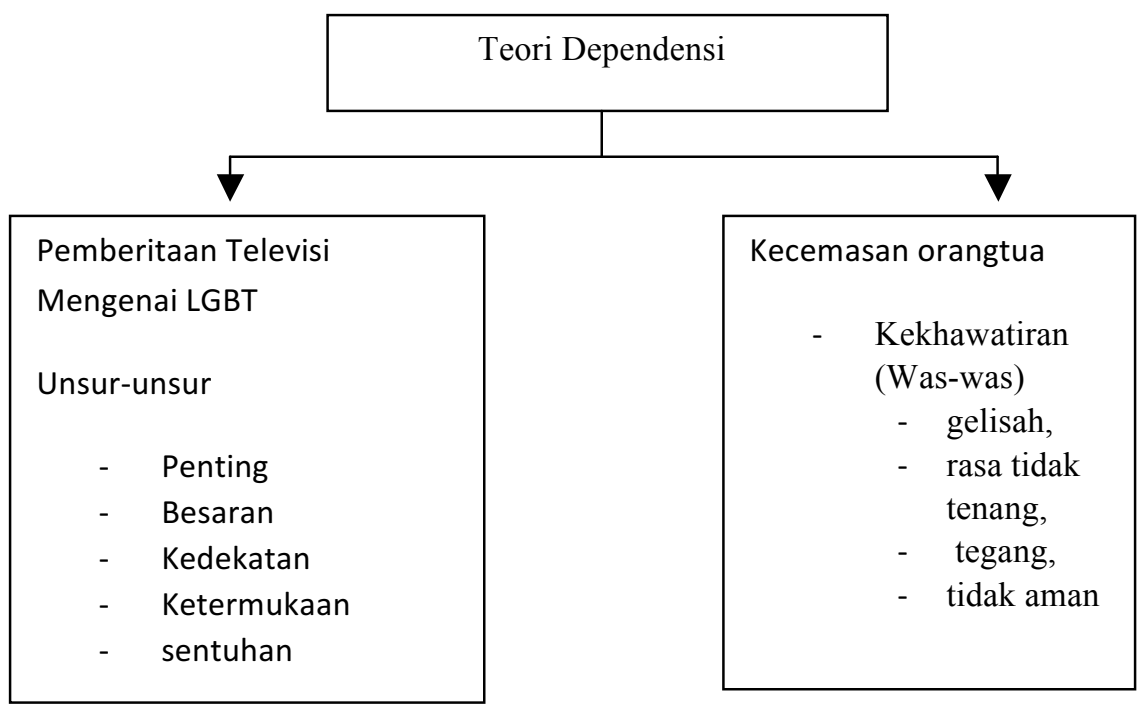

\section{Gambar 1. Krangka Pikir}

Berdasarkan kerangka pikir ini peneliti mejelaskan bahwa berita merupakan penyampaian suatu pesan atau informasi mengenai pemberitaan televisi yaitu LGBT yang di awali dari pesan/informasi yang disampaikan oleh komunikator kepada komunikan melalui saluran media, yaitu salah satunya media televisi sebagai sumber media terpercaya dan aktual dan bersifat audiovisual, akibat pemberitaan yang disampaikan oleh media massa televisi, secara tidak langsung menimbulkan efek media massa salah satunya yaitu efek afektif berupa kecemasan. Pada penelitan ini orang tualah yang banyak dalam menanggapi sebuah peristiwa atau fenomena yang sedang terjadi sebagai sumber pembelajaran atas pemberitaan yang disajikan oleh televisi. 


\section{PERSRESP}

Volume 1 Nomor 1. Juli - Desember 2018

\section{Hipotesis}

Dari latar belakang penelitian serta rumusan dan tujuan dari masalah penelitian, peneliti merumuskan hipotesis sebagai berikut :

$\mathrm{Ha}$ : Terdapat pengaruh nyata antara pemberitaan lesbian, gay, biseksual, transgender (LGBT) di televisi terhadap tingkat kecemasan orang tua di televisi.

Ho : Tidak terdapat pengaruh nyata antara pemberitaan lesbian, gay, biseksual, transgender (LGBT) di televisi terhadap tingkat kecemasan orang tua di televisi.

\section{METODE PENELITIAN}

Pendekatan penelitian yang digunakan dalam penelitian ini adalah pendekatan kuantitatif. Jenis penelitian yang digunakan dalam penelitian ini adalah jenis penelitian eksplanatif yaitu periset menghubungkan atau mencari sebab akibat antara dua atau lebih konsep (variabel) yang akan diteliti. Dalam penelitian ini, penulis menjelaskan pengaruh antara variabel $\mathrm{X}$ yaitu pemberitaan LGBT dengan variable Y tingkat kecemasan. Dalam penelitian ini penulis menggunakan metode survei, yaitu dengan cara penarikan sampel dari suatu populasi dan menggunakan kuesioner sebagai alat mengumpulkan data.

\section{Populasi dan Sampel}

Dalam penelitin ini populasi yang diambil yaitu pada warga Kelurahan Pondok Cina, Kecamatan Beji, Depok, Jawa Barat. Karena wilayah tersebut berdekatan dengan beberapa universitas yang secara tidak langsung berdekatan dengan kos-kosan mahasiswa. Teknik sampling yang digunakan oleh peneliti adalah nonprobabilitas sampling. Pada penelitian ini teknik sampling yang digunakan teknik sampling purposive (purposive sampling), yang menjadi sampel adalah warga Kelurahan Pondok Cina, Kecamatan Beji, Depok, Jawa Barat. Berdasarkan jumlah orang yang ditargetkan sebagai populasi lebih dari 1000 (seribu) jiwa, maka penarikan sampel dalam penelitian ini menggunakan rumus Yamane dengan presisi sebesar $10 \%$.

$$
\mathrm{N}=\frac{\mathrm{N}}{\mathrm{Nd}^{2}+1}
$$

\footnotetext{
Keterangan:

$\mathrm{n}=$ Besarnya ukuran sampel.

$\mathrm{N}=$ Besarnya populasi.
} 


\section{PERSERES}

$\mathrm{d}=$ Kelonggaran ketidak telitian karena kesalahan pengambilan sampel yang dapat ditolerir. Pada penelitian ini, penulis menggunakan batas toleransi $10 \%$.

Sampel pada penelitian ini adalah warga Kelurahan Pondok Cina, Kecamatan Beji, Depok, Jawa Barat.Jumlah Kependudukan Kelurahan Pondok Cina berjumlah 10936 jiwa. Dilansir dari (LaporanRegistrasi-Penduduk-Kecamatan-Beji.com)

$$
\begin{array}{ll}
\mathrm{n}= & \frac{10936}{10936.10 \%^{2}+1} \\
\mathrm{n}= & \frac{10936}{10936.0 .01+1} \\
\mathrm{n}= & \frac{10936}{110.36} \\
\mathrm{n}= & 99
\end{array}
$$

Sample yang didapat dari perhitungan dengan menggunakan rumus diatas didapat hasil sejumlah 99. Maka sampel yang akan diambil berjumlah 99 orang tua.

Validitas yang digunakan oleh penulis untuk mengukur dan menguji validitas dari korelasi variabel ini adalah Pearson's Product Moment, yang pengitungannya akan dilakukan dengan menggunakan software SPSS (Statistic Package Social Science) dengan menggunakan taraf signifikasi $10 \%$ atau 0.1 maka nilai $r$ tabel pada tabel dibawah yaitu 0.306 .

Uji Reliabilitas Untuk mengetahui alat ukur yang digunakan tidak berubah atau tetap, penulis melakukan uji reliabilitas. Dengan indikator yang sudah ditentukan, penulis dapat mengukur apakah pernyataan pada variabel X (pemberitaan LGBT di televisi) dan variabel Y (tingkat kecemasan) yang sebelumnya sudah ditentukan itu tepat dan tidak berubah saat digunakan lebih dari satu kali.

Teknik Pengumpulan Data Teknik pengumpulan data yang utama adalah angket atau kuesioner. Kuesioner merupakan teknik pengumpulan data yang dilakukan dengan cara memberi pertanyaan yang ditujukan pada responden untuk dijawabnya.

Dalam penelitian ini, skala pengukurannya menggunakan skala likert 1-4 dengan menghilangkan pernyataan ragu-ragu (biasa saja) karena tidak menggambarkan jawaban positif atau negatif terhadap suatu pendapat atau pernyataan. Teknik Analisis Data penulis menggunakan analisis bivariat, analisis ini untuk melihat hubungan dua variabel. Kedua variabel tersebut merupakan variabel pokok, yaitu variabel pengaruh (pemberitaan LGBT di TV) dan variabel terpengaruh (tingkat kecemasan). Dalam penelitian ini 


\section{PERSERES}

peneliti menggunakan regresi linier sederhana untuk mengukur besarnya hubungan variabel $\mathrm{X}$ yaitu pengaruh pemberitaan LGBT terhadap variabel Y yaitu Kecemasan.

$$
\mathrm{Y}=\mathrm{a}+\mathrm{bX}
$$

Keterangan:

Y: Variabel tidak bebas

$\mathrm{X}$ : Variabel bebas

a: Nilai intercept (konstan) atau harga $\mathrm{Y}$ bila $\mathrm{X}=0$.

b: Koefisien regresi, yaitu angka peningkatan atau penurunan variabel dependen yang didasarkan pada variabel independen.

Uji T (Hipotesis) Untuk menguji hipotesis penulis mengunakan Uji T. Untuk menentukan Uji T penelitian ini menggunakan cara manual dan langkah-langkahnya sebagai berikut:

$$
t=\frac{r \sqrt{n-2}}{\sqrt{1-r^{2}}}
$$

Keterangan:

$\mathrm{r}=$ koefisien korelasi.

$\mathrm{n}=$ jumlah responden $(\mathrm{n}-2=\mathrm{dk}$, derajat kebebasan $)$.

\section{PEMBAHASAN}

Hasil penelitian ini dianalisis menggunakan uji analisis statistik, yang terdiri dari analisis deskriptif dan analisis inferensial. Analisis deskriptif dilakukan untuk menjelaskan karakteristik responden. Adapun karakteristik responden yaitu jenis kelamin, usia, kemudian pendidikan. Selain itu analisis deskriptif juga untuk menjelaskan hasil penelitian dari pemberitaan LGBT di televisi dan tingkat kecemasan.

Pada variabel pemberitaan LGBT di televisi terdapat 6 dimensi diantaranya yaitu penting (mempunyai pengaruh yang besar terhadap kehidupan orang banyak, mempunyai akibat atau dampak yang luas), besaran (sesuatu yang besar dari segi jumlah, nilai, atau angka yang besar hitungannya sehingga pasti menjadi suatu yang berarti \& menarik untuk diketahui banyak orang), kebaruan (memuat suatu peristiwa yang baru saja terjadi, karena kejadiannya belum lama, hal ini menjadi aktual atau masih 


\section{PESRERES}

hangat untuk diperbincangkan), kedekatan (suatu peristiwa atau kejadian yang memiliki kedekatan jarak ataupun emosional dengan khalayak). Ketermukaan (peristiwa yang menyangkut orang terkenal atau suatu yang dikenal oleh masyarakat menjadi berita penting untuk diketahui oleh khalayak), sentuhan (sesuatu yang menyangkut rasa kemanuasiaan, mengguga hati, dan minat). Sementara pada variabel Y yaitu tingkat kecemasan terdapat 1 dimensi yaitu ke khawatiran (was-was) dan 4 indikator yaitu gelisah, rasa tidak tenang, tegang, tidak aman .

\section{Karakteristik Responden}

Karakteristik responden dalam penelitian ini yaitu berdasarkan jenis kelamin, usia dan pendidikan. Berikut ini adalah tabel yang menunjukan perolehan hasil dari data karakteristik responden

Tabel 1. Karakteristik Responden

\begin{tabular}{|l|c|c|c|}
\hline \multicolumn{2}{|c|}{ Karakteristik Responden } & Frekuensi & Presentase (\%) \\
\hline Jenis Kelamin & Laki-laki & 29 & 29,3 \\
& Perempuan & 70 & 70,7 \\
& total & 99 & 100 \\
\hline Usia & $20-30$ th & 33 & 33 \\
& $31-50$ th & 59 & 60 \\
& $>50$ th & 7 & 7 \\
\hline Tingkat Pendidikan & Total & 99 & 100 \\
& SMA & 89 & 89,9 \\
& Diploma & 6 & 6,1 \\
& Sarjana & 4 & 4 \\
& Total & 99 & 100 \\
\hline
\end{tabular}

Dari hasil olah data pada data jenis kelamin responden menunjukkan kaum perempuan yaitu berjumlah 70 orang dengan persentase $70,7 \%$, sementara responden laki-laki yaitu berjumlah 29 orang dengan persentase 29,3\% dari total responden sebanyak 99 orang. Dari hasil statistik data kependudukan berdasarkan jenis kelamin warga kelurahan Pondok Cina, kecamatan Beji, Depok bahwa laki-laki sebanyak 6.038 dan perempuan sebanyak 5.295. Pemerintah kota Depok, kecamatan Beji (diakses 8 juni 2016, 20:00 wib) http://beji.depok.go.id/profil/kependudukan Responden dengan presentase tertinggi pada faktor jenis kelamin dari kuesioner pada saat penulis menyebar pada warga kelurahan Pondok Cina, Depok, Jawa Barat adalah perempuan sebanyak 70,7\%, hal ini dikarenakan sebagian responden perempuan lebih sering berada di rumah, selain itu intensitas menonton televisi lebih sering dilakukan oleh kaum ibu dibandingkan pria. Oleh karena itu ibu rumah tangga lebih mengetahui pemberitaan LGBT 


\section{PERSRESI}

Volume 1 Nomor 1. Juli - Desember 2018

\section{Pemberitaan LGBT di televisi}

Pemberitaan dalam penelitian ini yaitu mengenai pemberitaan LGBT di televisi. Hasil penelitian skor rata-rata pemberitaan LGBT di televisi pada tabel berikut:

Tabel 2. Nilai Rata-Rata Pemberitaan LGBT

\begin{tabular}{|l|l|c|}
\hline \multicolumn{1}{|c|}{ No. } & \multicolumn{1}{|c|}{ Dimensi } & Mean (Rata-rata) \\
\hline 1 & Penting & 2,99 \\
\hline 2 & Besaran & 2,92 \\
\hline 3 & Kebaruan & 3,20 \\
\hline 4 & Kedekatan & 3,12 \\
\hline 5 & Ketermukaan & 3,17 \\
\hline 6 & Sentuhan & 3,05 \\
\hline & Total & 3,06 \\
\hline
\end{tabular}

Berdasarkan tabel di atas, dimensi yang memiliki skor rata-rata tertinggi dalam pemberitaan LGBT di televisi adalah dimensi ketermukaan. Dimensi ketermukaan memperoleh skor sebesar 3,17. Dari hasil tersebut dapat disimpulkan bahwa rata - rata responden setuju dengan dimensi ketermukaan pada pemberitaan LGBT. Selain itu pemberitaan LGBT juga sangat diketahui masyarakat contohnya pemberitaan kaum LGBT yang meminta agar statusnya dilegalkan pemerintah. Pemberitaan LGBT juga menyangkut orang terkenal berupa publik figur.

Berdasarkan tabel rata-rata, dimensi yang memiliki skor rata-rata terendah dalam pemberitaan LGBT di televisi adalah dimensi besaran. Besaran merupakan sesuatu yang besar dari segi jumlah, nilai atau angka yang besar hitungannya sehingga pasti menjadi suatu yang berarti dan menarik untuk diketahui oleh orang banyak. Dimensi besaran memperoleh skor sebesar 2,92.

\section{Tingkat Kecemasan}

Kecemasan dalam penelitian ini yaitu mengetahui sikap orang tua setelah melihat pemberiataan LGBT di televisi. Kecemasan menyebabkan munculnya rasa gelisah, tegang, tidak tenang, dan merasa tidak aman, dalam penelitian ini perasaan tidak cemas dapat dilihat melalui pengaruh media televisi yang menyiarkan berita mengenai LGBT. 
Tabel 3. Kecemasan

\begin{tabular}{|c|c|c|}
\hline No. & Indikator & Mean \\
\hline 1 & Gelisah & 3,04 \\
\hline 2 & Rasa tidak tenang & 2,96 \\
\hline 3 & Tidak aman & 2,95 \\
\hline 4 & Tegang & 3,04 \\
\hline & Jumlah & 3,00 \\
\hline
\end{tabular}

Sumber: diolah

Berdasarkan tabel di atas, Maka dapat disimpulkan bahwa rata-rata responden merasa kekhawatiran setelah melihat pemberitaan LGBT yang disampaikan pada televisi. Indikator Gelisah dan Tegang skor rataan yang sama yaitu 3,04. Hal ini dilakukan karena khalayak atau orang tua yang menyaksikan pemberitaan tersebut tidak menginginkan orang terdekatnya menjadi LGBT.

\section{Analisis Inferensial}

Uji Regresi Regresi linear sederhana digunakan untuk mengetahui besarnya pengaruh pemberitaan LGBT di televisi terhadap tingkat kecemasan orang tua. Koefisien regresi merupakan suatu konstribusi besarnya perubahan nilai variabel bebas (x). Semakin besar nilai koefisien regresi, maka konstribusi perubahan semakin besar dan sebaliknya, semakin kecil nilai koefisien regresi, maka konstribusi perubahan semakin kecil. Konstribusi perubahan variabel $\mathrm{X}$ juga ditentukan oleh koefisien regresi positif dan negatif. Hasil uji regresi pada pemberitaan LGBT di televisi terhadap tingkat kecemasan orang tua adalah sebagai berikut:

Tabel 4.

Uji Pengaruh Pemberitaan LGBT Terhadap Tingkat Kecemasan Orang tua

\begin{tabular}{|c|c|}
\hline Hasil Uji & R Square \\
\hline Pengaruh & 0,500 \\
\hline
\end{tabular}

Dari perhitungan SPSS di atas, maka diketahui koefesien regresi sebesar 0,500 dikarenakan hasil positif (+), maka angka variabel tingkat kecemasan (dependen) naik. Kesimpulannya, bahwa terdapat pengaruh dari pemberitaan LGBT di televisi terhadap tingkat kecemasan orang tua. Dalam melihat seberapa besar kontribusi pengaruh pemberitaan LGBT di televisi terhadap tingkat kecemasan orang tua pada warga Kelurahan Pondok Cina, Kecamatan Beji, Depok, Jawa Barat, haruslah dicari koefisien determinasi terlebih dahulu. Koefisien determinasi dihitung dengan cara mengkuadratkan hasil korelasi kemudian dikalikan dengan 100\% seperti rumus sebagai berikut : 


\section{PESRERES}

$$
\mathrm{Kd}=\mathrm{r}^{2} \times 100 \%
$$

Keterangan :

$\mathrm{Kd}:$ Koefisien determinasi

$\mathrm{r}$ : koefisien korelasi

Maka:

$$
\mathrm{Kd}=0,500 \times 100 \%=50 \%
$$

Dapat disimpulkan bahwa pengaruh pemberitaan LGBT di televisi terhadap tingkat kecemasan orang tua pada warga Kelurahan Pondok Cina, Kecamatan Beji, Depok, Jawa Barat sebesar 50\% sedangkan sisanya 50\% ditentukan oleh faktor lain yang tidak diteliti oleh penulis.

\section{Uji Hipotesis}

Setelah diketahui sejauh mana pengaruhnya antara kedua variabel, maka langkah berikutnya yaitu melakukan uji hipotesis. Hal ini dilakukan untuk menguji apakah ada pengaruh atau hubungan yang signifikan antara pemberitaan LGBT di televisi terhadap tingkat kecemasan orang tua pada warga Kelurahan Pondok Cina, Kecamatan Beji, Depok, Jawa Barat.

$\mathrm{Ha}$ : terdapat pengaruh pemberitaan LGBT di televisi terhadap tingkat kecemasan orang tua pada warga Kelurahan Pondok Cina, Kecamatan Beji, Depok, Jawa Barat

a. Jika $t$ hitung $>t$ tabel, maka Ha dapat diterima dan Ho ditolak (ada hubungan)

b. Jika $t$ hitung $<\mathrm{t}$ tabel, maka Ha ditolak dan Ho diterima (tidak ada hubungan)

Rumus uji t sebagai berikut:

$$
t=\frac{r \sqrt{n-2}}{\sqrt{1-r^{2}}}
$$

Keterangan :

$\mathrm{t}$ : Nilai uji $\mathrm{t}$

r : Koefisien korelasi

$\mathrm{n}$ : Banyak sampel yang di observasi

Maka t hitung:

$$
\begin{gathered}
t=\frac{0,707 \sqrt{99-2}}{\sqrt{1-(0,707 \times 0,707)}} \\
0,707 \sqrt{97}
\end{gathered}
$$




\section{PERSRESI}

$$
\begin{aligned}
& \mathrm{t}=\frac{0,707 \times 9,8}{\sqrt{1-0,49}} \\
& \mathrm{t}=\frac{6,92}{\sqrt{1-0,49}} \\
& \mathrm{t}=\frac{0,714}{\mathrm{t}=}
\end{aligned}
$$

Keputusan untuk menentukan kesimpulan signifikasi adalah dengan cara membandingkan t hitung dengan $\mathrm{t}$ tabel. Dari $\mathrm{t}$ tabel nilainya ditentukan dengan menggunakan tingkat signifikasi $10 \%$ dan $\mathrm{df}=\mathrm{n}-2(99-2$ =97), maka nilai t tabelnya adalah 1,66. Berdasarkan hasil penghitungan diatas didapat bahwa: $\mathrm{t}$ hitung $>\mathrm{t}$ tabel yaitu 9,691 > 1,661 maka Ho ditolak. Dapat disimpulkan yaitu terdapat pengaruh pemberitaan LGBT di televisi terhadap tingkat kecemasan orang tua pada warga Kelurahan Pondok Cina, Kecamatan Beji, Depok, Jawa Barat.

\section{SIMPULAN}

Kesimpulan Berdasarkan hasil penelitian yaitu analisis data dan pembahasan yang telah penulis uraikan pada bab sebelumnya, maka penulis dapat menyimpulkan sebagai berikut : Bahwa terdapat pengaruh nyata pemberitaan LGBT di televisi terhadap tingkat kecemasan orang tua pada warga Kelurahan Pondok Cina, Kecamatan Beji, Depok, Jawa Barat sebesar 50\%, sehingga Ho ditolak.

\section{REFERENSI}

Ardianto, Elvinaro 2014, Komunikasi Massa Suatu Pengantar. Simbiosa Rekatama Media, Bandung.

Baksin, Askurifai 2006, Jurnalistik Televisi teori dan praktik, PT Remaja Rosdakarya, Bandung.

Dewi, Mustika 2013,'Pengaruh Tayangan Berita Kriminal di televisi terhadap Kecemasan Ibu Rumah Tangga akan Tindak Kejahatan Anak di Samarinda', Ilmu Komunikasi, Vol.1 No.4, hlm. 150-162, diakses pada 8 Maret 2016. http://ejournal.ilkom.fisip-unmul.ac.id/site/wp content/uploads/2013/11/02_format_artikel_ejournal_mulai_hlm_genap\%20(1118-13-02-5222).pdf

Kristina, Shinstya 2012, 'Informasi dan Homoseksual - Gay (Studi Etnometodologi Mengenai Informasi dan Gay Pada Komunitas Gaya Nusantara Surabaya)', hlm. 1-19, diakses pada 28 Juni 2016. https://www.google.co.id/url? sa $=$ t\& $r c t=j \& q=\&$ esrc $=$ s\&source $=$ web\&cd $=2 \& c a d=r j$ a\&uact=8\&ved=0ahUKEwi7gf6xiMnNAhWBpY8KHSKCDVkQFgggMAE\&url=http\%3 $\mathrm{A} \% 2 \mathrm{~F} \% 2 \mathrm{Fjournal.unair.ac.id} \% 2 \mathrm{Fdownload}-$ 


\section{PERSRESI}

fullpapersjurnal\%2520shinstya.doc\&usg=AFQjCNHNdiAWcjXCaMqsGjwRK7Ko8RFBuw\&bvm =bv.125596728,d.c2I

Matthew, Hargenhan 2013, Pengantar Teori Kepribadian, Pustaka Belajar, Yogyakarta.

Morissan 2013, Manajemen Media Penyiaran strategi mengelola radio dan televisi. Kencana Prenada Media Group, Jakarta.

Morissan 2008, Jurnalistik Televisi Mutakhir, Kencana Prenada Media Group, Jakarta.

Nurkholis 2013, 'Faktor-Faktor yang Melatar belakangi Lesbian dan Kodisi Psikologisnya', vol 1, No.1 hlm. 1, diakses pada 28 Juni 2016. http://ejournal.umm.ac.id/index.php/jop/article/view/1453

Rassan 2013, Transgender, hlm. 1-20, diakses pada 29 Juni 2016. www.google.co.idgws_rd=cr\&ei=7mNxV9f4B8nuvgSsvYqgBw\#q=jurnal+penelitian +transgender

Sarwono, Sarlito 2010, Pengantar psikologi umum, PT Raja Grafindo Persada, Jakarta.

Sianturi 2011,'Psychological Well-Being, Individu Biseksual', hlm. 19-31, diakses pada 28 Juni 2016. http.repository.usu.ac.idbitstream123456789295103Chapter\%20II.pdf

Siska, Sudardjo, Hesti 2003, Kepercayaan Diri dan Kecemasan Komunikasi Interpersonal pada Mahasiswa, hlm. 67-71, diakses pada 28 Juni 2016. www.google.co.idsearchbiw $=1280 \& b i h=665 \& q=j u r n a l+k e c e m a s a n+k o m u n i k a s i \& s$ $\mathrm{a}=$ X\&ved=0ahUKEwi3ztWwlMnNAhVItY8KHe6hALkQ1QIIYCgD

Internet

Siapa Firmansyah Sosok Aktivis Gay Yang Mengaku Mendirikan SGRC, diakses 28 Maret 2016, http://nasional.republika.co.id/berita/nasional/umum/16/01/22/o1c56r318siapa-firmansyah-sosokaktivis-gay-yang-mengaku-mendirikan-sgrc-ui

\section{BIODATA}

Afif Rahman Kurnia mahasiswa Prgram Studi Ilmu Komunikasi Fakultas Ilmu Sosial dan Ilmu Politik Universitas Pembangunan Nasional Veteran Jakarta pada 2012, aktif sebagai Kepala Operasional crew Five TV UPN Veteran Jakarta, kini bekerja di Stasiun televisi nasional di Jakarta.

Rini Riyantini merupakan dosen program studi Ilmu Komunikasi Fakultas Ilmu Sosial dan Ilmu Politik Universitas Pembangunan Nasional Veteran Jakarta, selain mengajar, pernah menjabat sebagai Ketua Program Studi Ilmu Komunikasi dan Wakil Dekan 1 FISIP UPNVJ, kini tengah menjabat sebagai Ketua Sistem Penjamin Mutu Internal UPN Veteran Jakarta. 